\title{
Design of a Flyover and Roundabout underneath it to ease the Traffic Congestion at the Rajagiriya Junction
}

\author{
P. L. Mututantri, W. D. P. Abeysinghe, L. S. S. Wijewardena and \\ K. S. Weerasekera
}

\begin{abstract}
Urban traffic congestion has become a serious concern of transportation professionals and traffic managers. Rajagiriya town becomes severely congested due to vehicular traffic during daytime. Therefore, efforts were made to quantify this congestion and formulate appropriate measures to mitigate it. Rajagiriya town consists of several intersections located at close proximity to one another, and they have become potential sources of acute traffic congestion. There are three junctions situated along the main road (i.e. Sri-Jayewardenepura road) namely Police station junction, Bo-tree junction and the Kohilawatta road junction.
\end{abstract}

In order to find a solution to this traffic congestion, the capacities of the roads were evaluated by compiling data related to prevailing vehicular flows and collecting other supportive information both as of today and for the next 20 years (i.e. up to the year 2035). From the capacity calculations made from field data it is evident that all the roads in the area would fail to cater to the future traffic demands. Road widths, lanes and walkway shoulders were designed using the U. S. Highway Capacity Manual so as to meet the anticipated traffic demands and pedestrian requirements of the future, [1].

As a solution to ease the transportation problems mentioned, initiatives were taken to separate out the traffic flows by constructing a flyover. The design of the flyover was done considering a heavy traffic movement and the flyover was so located that it did not hinder the three junctions. The location for the flyover was decided based on the prevailing operating conditions. For the flyover, pre-stressed material was proposed as it is found to be economical whereas pre-stressed concrete and in-situ concrete were proposed for the beams and piers respectively.

Roundabouts were found to be a suitable solution to manage the traffic flow under the flyover. The roundabout design was done using a turning template and based on the Australian Standards (AUSTROADS) [2]. The selection and the design of a roundabout, as with any intersection, require the balancing of competing objectives such as safety, operational performance, and accessibility for all users. Factors such as land use, aesthetics, and environmental aspects too were considered. Flexible concepts allow room for independent designs and techniques tailored for a particular situation while emphasizing performance based evaluation of those designs.

Finally a suitable layout plan was introduced for the study.

Keywords: Flyover, Roundabout, Traffic flow, Traffic congestion

\section{Introduction}

The town of Rajagiriya, the area under study, administered by the Kotte Municipal Council is situated about $10 \mathrm{~km}$ away from the centre of Colombo, the commercial capital of Sri Lanka. There are supermarkets, schools, religious places, educational centres, a children's park and government and private sector institutions located in this area. There are three junctions in the town namely, "Police station junction, "Bo-tree junction", and "Kohilawatta junction" (Figure 1)and all these three junctions have been considered in this
P. L. Mututantri, Undergraduate, Department of Civil Engineering, The Open University of Sri Lanka

W. D. P. Abeysinghe, Undergraduate, Department of Civil Engineering, The Open University of Sri Lanka.

Eng. L. S. S. Wijewardena, BSc Eng. (Hons.) (Peradeniya), M.Eng.(AIT), C.Eng., MIE(SL), MIHT(UK), Senior Lecturer Grade I, Department of Civil Engineering, The Open University of Sri Lanka.

Eng. (Prof.) K. S. Weerasekera,BSc Eng (Moratuwa), MEngSc (UNSW), PhD (UNSW), FIE(SL), CEng, IntPE(SL), MIE (Aust), CPEng, MIHT(UK), MASCE, Chair and Professor of Civil Engineering, Department of Civil Engineering, The Open University of Sri Lanka. 
study. Heavy traffic congestion is observed in the town of Rajagiriya during morning, afternoon and evening rush hours. There are many simultaneous and conflicting movements at these junctions. A motorist approaching Borella via Rajagiriya along Kotte road and Nawala - Rajagiriya road has to undergo much inconvenience especially during peak hours. During off-peak hours, the congestion is not that severe. In the morning, traffic flows mainly towards Colombo and in the evening, its direction reverses. The three junctions mentioned above are the primary points that lead to this traffic congestion.

The road sections under this study encounters huge traffic towards Battaramulla, Parliament road and also towards Obeysekarapura, Borella and Kollupitiya and on these road sections a large number of public transport buses ply along with hundreds of other privately owned vehicles. Buses take a considerably long time to pass Rajagiriya in moving towards Nawala and Kohilawatta. The three junctions hinder the flow of traffic along the main route thereby increasing traffic congestion along the main route (i.e. Sri Jayawardhanapura road).

Many government offices and public institutions outside the Colombo city centre are located close to the study area resulting in an increase in the traffic flow(e.g. Sethsiripaya, Isurupaya, Parliament etc.) to this area. Vehicles arriving at these destinations use this route daily leading to an increase in the daily traffic flow. The unavailability of dedicated parking lanes or slots compels the drivers to park their vehicles along the road, and this too has contributed to the increased traffic congestion.

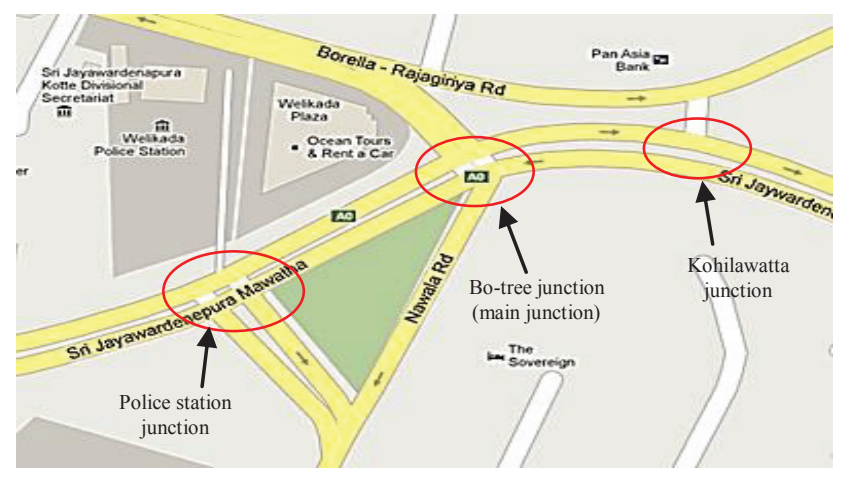

Figure 1 - Location of the Study Area

Traffic congestion can cause several problems such as economic costs resulting from delayed travel times, increase fuel consumption, air pollution and accidents. When one roadway gets congested, drivers tend to use other alternative routes which necessarily may not have been meant to be used by vehicles. Getting caught in these traffic congestions can cause mental stress to the road users leading to various health issues.

The present traffic signal system at the Rajagiriya junction is not working satisfactorily. Even if it does work satisfactorily, it is functioning below the expected standard and therefore is inadequate to ease the traffic congestion. In addition to introducing a sound solution for this issue, the implementation of a proper traffic signal system suitable for this geometry or an introduction of a flyover at the junction has to be considered. Furthermore, an adequate number of lanes should be established a teach approaching intersection to cater to the expected traffic flows.

\section{Aim and Objectives}

The aim of this study is to observe whether the existing road capacities are adequate to cater to the current traffic volumes and if found inadequate to design the road and intersections in such a way so as to cater to the anticipated future traffic. This study also hopes to propose ways and means of improving the roads by introducing appropriate road widths and a few lanes in the study area to cope up with the traffic needs to provide a satisfactory level of service. The outcome of this study is expected to introduce a suitable solution to ease the projected traffic congestion at the Police station junction, Bo-tree junction and Kohilawatta road junction.

Towards fulfilling this aim, the objective of the study would be to justify and design a solution for the safe movement of vehicular traffic at the Rajagiriya junction by paying attention to the following:

1. Identification of peak hours based on available traffic data.

2. Conduct of turning movement surveys of traffic at the respective junctions during peak hours on week days.

3. Identification of the road widths and the number of lanes currently available to determine future requirements. 
4. Determination of the most suitable flyover layout with a twenty year life span to ease out the traffic congestion at the junction, by taking into consideration typical traffic growth rates.

5. Designing the roundabout to ease out the traffic underneath the flyover.

6. Carrying out the structural design of the proposed flyover.

7. Proposing a final solution for the existing traffic related problems at the Rajagiriya intersection.

\section{Methodology}

\subsection{Data Collection}

The methodology adopted to identify the flyover at the Rajagiriya junction was through a highway traffic analysis using the following:

- Identification of the existing geographical and layout arrangements of the project area.

- Conducting a survey to identify the main commercial, school and office buildings and public institutions located in the area.

- Accurate identification of the locations of buildings in the area using Google maps.

- Identification of the road network in the project area using the existing road survey drawings of the Road Development Authority (RDA) and Google maps.

- Measurement of the existing road and shoulder widths accurately.

- Obtaining from the RDA, the traffic count data of the past years at the Colombo city entry point to determine AADT and growth rates.

- Conducting turning movement surveys for identified locations.

- Checking the available pre-stressed beam sizes and lengths.

\subsection{Traffic Study}

- Identification of the peak period using turning movement survey results.

- Obtaining the Level of Service (LOS) from the existing road section.

- Introduction of a flyover bridge to cater to the main traffic flows.

- Carrying out the traffic volume forecast for the next twenty years.
- Separating out traffic flows expected to pass over the bridge and under the bridge.

- Calculation of the required number of lanes for the flyover bridge and the intersection.

- Checking LOS after a period of twenty years for the traffic passing over the flyover and underneath the flyover to verify the future scenario.

- Introduction of a roundabout underneath the flyover.

- Evaluation of the number of lanes required in the roundabout and turning movement details.

- Conversion of the number of vehicles to Passenger Car Unit(PCU) values.

- Determination of the gap acceptance, capacity analysis and queuing delays in the roundabout according to AUSTROADS guidelines [2].

- Determination of the inscribed circle diameter of the proposed roundabout considering the existing available land area and finding out the rotary carriage width and radius of the central island.

- Selection of suitable dimensions for the roundabout according to the geometric data and preparation of the detail drawings.

- Obtaining the horizontal and vertical curve lengths for the flyover at a design speed of $72 \mathrm{~km} / \mathrm{h}$.

- Checking head lamp visibility during night time at a design speed of $72 \mathrm{~km} /$ has set out in the highway design capacity manual 2012 [3].

\subsection{Structural Design of the Flyover}

- Piers were introduced to the flyover taking in to consideration the maximum span of the available beams (25m) so as to ensure minimum obstruction to the access roads to the Rajagiriya junction.

- Pre-stressed concrete beams were designed using BS 5400 [4].

- Piers were designed according to the guidelines given in BS 5400 [4].

\section{Data and Analysis}

\subsection{Identification of the Peak Hours}

The traffic flow along a road does not remain constant throughout a day or week but varies with both space and time. The peak hour represents the most critical period for operations and has the highest capacity 
requirements for a given location. Three peak hours of the day were identified from the traffic data collected from the RDA at fifteen minute intervals in the morning, mid-day and evening peaks respectively for the Police station junction, Bo-tree junction and Kohilawatta road junction. Traffic surveys were carried out from 6:30 am to 9:30 am, 12:00 pm to $3: 00 \mathrm{pm}$ and from 4:30 pm to 7:30 pm. Figure 2 shows the observed number of vehicles during the time periods mentioned. From Figure 2 it can be seen that the peakhour would be between 5:30pm and 6:30pm.

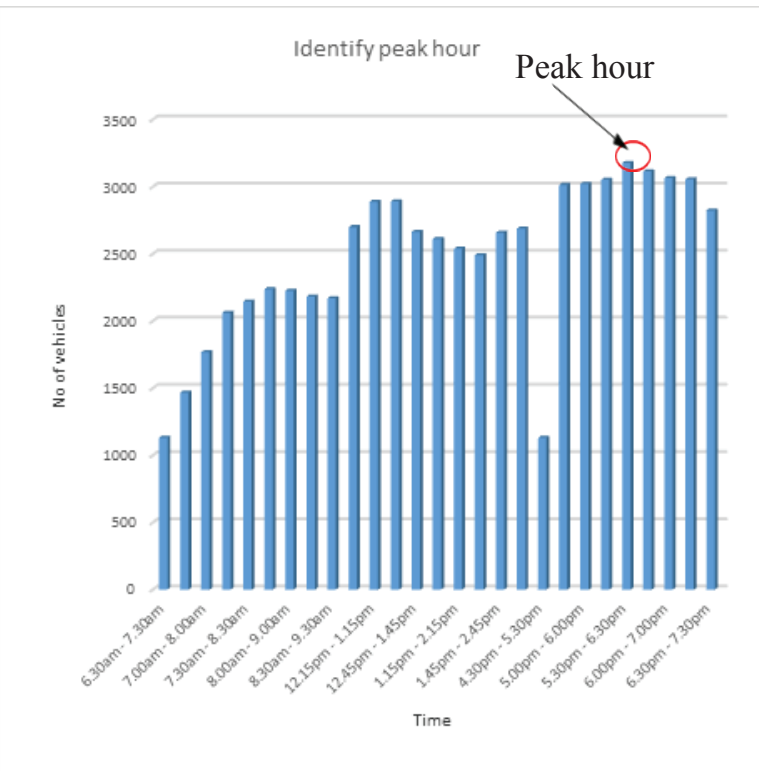

Figure 2 - Traffic flow

\subsection{Detailed Survey Drawing of the} Selected Area

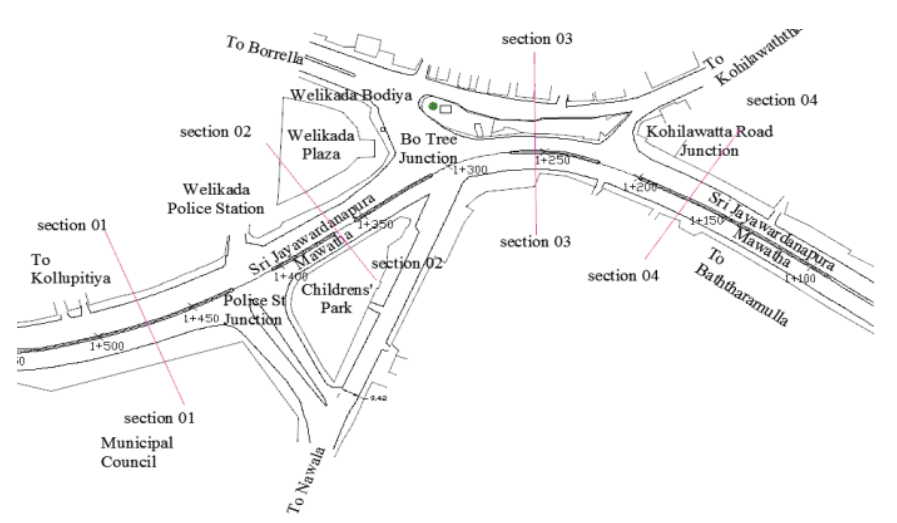

Figure 3 - Detailed Survey Drawing

In Figure 3, dimensions such as center lines, chainages, earmarked boundaries for future widening, building corners and the radius of existing horizontal curves are indicated.

\section{3 Analysis of the Traffic Flow Volume \& Capacity}

The US Highway Capacity Manual was used to calculate the LOS at each section of the existing road. In making this calculation the following basic relationships were used:

$$
\begin{aligned}
& P H F=\frac{V}{4 \times V_{15}} \\
& S F=\frac{V}{P H F} \\
& S F_{i}=C_{j} \times(v / c)_{i} \times N \times f_{w} \times f_{E} \times \\
& f_{H V} \times f_{p} \\
& f_{H V}=\frac{1}{\left[1+P_{T}\left(E_{T}-1\right)+P_{B}\left(E_{B}-1\right)\right]}
\end{aligned}
$$

where,

$$
\begin{aligned}
& \text { PHF } \text { - Peak hour factor } \\
& V \text { - Hourly volume } \\
& V_{15} \quad \text { - Highest } 15 \text { minute volume } \\
& S F_{i} \quad \text { - Service flow rate; the maximum flow } \\
& \text { rate in vph that can be } \\
& \text { accommodated by the multilane } \\
& \text { highway segment under study, in } \\
& \text { one direction, under prevailing } \\
& \text { roadway and traffic conditions, } \\
& \text { while meeting the performance } \\
& \text { criteria of LOS }
\end{aligned}
$$

$C_{j} \quad$ - Capacity per lane for a multilane highway with design speed

$N \quad$ - Number of lanes in one direction

$(v / c)_{i}$ - Maximum volume-to-capacity ratio while maintaining the performanceCharacteristics of $\operatorname{LOS}_{i}$

$f_{w} \quad$ - Adjustment factor for lane width and/or lateral clearance restrictions

$f_{H V} \quad$ - Adjustment factor for the presence of heavy vehicles in the traffic stream

$f_{E} \quad$-Adjustment factor for the development environment and type of multilane highway

$f_{p} \quad$-Adjustment factor for driver population 


$$
E_{T}, E_{B}-\begin{gathered}
\text { Passenger-car equivalents for trucks } \\
\text { and buses }
\end{gathered}
$$

$$
P_{T}, P_{B} \begin{gathered}
\text { - Proportion of trucks and buses in the } \\
\text { traffic stream }
\end{gathered}
$$

\subsection{Level of Service Criteria (LOS)}

The level of service criteria for multilane and two lane highways are defined in terms of vehicle density [1]. The complete LOS criteria are given in the US Highway Capacity Manual at the design speeds of $70 \mathrm{mph}, 60 \mathrm{mph}$ and $50 \mathrm{mph}$. This gives the average travel speeds, and the Maximum Service Flow (MSF)rate at each level of service.

\subsection{Determination of the current LOS}

The LOS was calculated for the Kollupitiya to Battaramulla direction Section 1-1 shown in Figure 3. The volume was calculated using the summation of the turning movement survey volumes from Kollupitiya to Battaramulla and Kollupitiya to Nawala at the Police station

\begin{tabular}{|c|c|}
\hline No of lanes & $=3$ \\
\hline Full hour volume & $=3177 \mathrm{vph}$ \\
\hline Maximum 15 min volume & $=821 \mathrm{vph}$ \\
\hline Peak hour factor & $\begin{aligned}= & \\
& 3177 /(4 \times 821) \\
= & 0.97\end{aligned}$ \\
\hline Service flow rate & $\begin{array}{l}=3177 / 0.97 \\
=3275 \mathrm{vph}\end{array}$ \\
\hline Distance of travelled pavement & $=6 \mathrm{ft}$ \\
\hline Lane width & $=9.5 \mathrm{ft}$ \\
\hline $\mathrm{f}_{\mathrm{w}}$ & $=0.84$ (Table \\
\hline
\end{tabular}
junction.

The peak hour volume during the period from 5:30 pm to $6: 30 \mathrm{pm}$ was considered.

Highway Capacity Manual 1985)

Multilane highway is divided and suburban

$$
\mathrm{f}_{\mathrm{E}} \quad 0.90 \text { (Table } 7.10-
$$

Highway Capacity Manual 1985)

Adjustment factor for heavy vehicles $\left(\mathrm{F}_{\mathrm{HV}}\right)$,

Percentage of trucks $=118 / 3177$

$$
\left(\mathrm{P}_{\mathrm{T}}\right) \quad=0.04
$$

Percentage of buses $\quad=19 / 3177$

$$
\left(\mathrm{P}_{\mathrm{B}}\right) \quad=0.006
$$

Passenger car equivalent factor for trucks

$$
\left(\mathrm{E}_{\mathrm{T}}\right) \quad=1.7
$$

Passenger car equivalent factor for buses

$$
\left(\mathrm{E}_{\mathrm{B}}\right) \quad=1.5
$$

(Table 7.3 - Highway Capacity Manual 1985)

$\mathrm{F}_{\mathrm{HV}} \quad=1 /\left(1+\mathrm{P}_{\mathrm{T}}\left(\mathrm{E}_{\mathrm{T}}-1\right)+\mathrm{P}_{\mathrm{B}}\left(\mathrm{E}_{\mathrm{B}}-1\right)\right)$

$$
\begin{aligned}
& =1 /(1+0.04(1.7-1)+0.006(1.5-1)) \\
& =0.97
\end{aligned}
$$

For a Design speed of $50 \mathrm{mph}$

No of lanes $=3$

C $\quad=2000$ (Table 3.1 - Highway

capacity manual)

$$
\begin{aligned}
& \mathrm{v} / \mathrm{C} \quad=\mathrm{SF} /\left(\mathrm{Cj} \times \mathrm{N} \times \mathrm{F}_{\mathrm{W}} \times \mathrm{F}_{\mathrm{HV}} \times \mathrm{F}_{\mathrm{E}} \times \mathrm{F}_{\mathrm{P}}\right) \\
& =3275 /(1900 \times 3 \times 0.84 \times 0.97 \times 0.90 \times 1) \\
& =0.788
\end{aligned}
$$

It is seen that the current LOS for this stretch is E which is unsatisfactory. The existing road stretches where LOS is lower than D need to be improved.

\subsection{Traffic Volume Forecast}

Using the existing traffic volumes and relevant growth factors obtained from the RDA, the future traffic in the study area was computed. This helped to foresee the traffic demand in another 20 years from now. This in turn helped to decide the highway capacity for a suitable level of service for the time period concerned.

The morning peak hour flows were taken towards Colombo direction and evening peak hour flows were taken for the opposite direction.

The growth rates can be calculated as follows: Predicted traffic volume

$$
=(\text { Existing traffic volume }) \times(1+g)^{n}
$$

Table 1 - Growth Rates for Passenger Cars

\begin{tabular}{|c|c|c|c|c|}
\hline $2010-$ & $2012-$ & $2017-$ & $2022-$ & $2027-$ \\
2012 & 2017 & 2022 & 2027 & 2032 \\
\hline 5.2 & 4.3 & 4.1 & 3.6 & 2.8 \\
\hline
\end{tabular}

From Kollupitiya to Battaramulla at Police station Junction

Sample Calculation:

Existing traffic volume of passenger cars $(6: 30 \mathrm{am}-6: 45 \mathrm{am})=90$

Predicted traffic volume during the period from the year 2013 to the year 2017

$$
\begin{aligned}
\text { Number of years } & =4 \\
\text { Traffic volume in } 2017 & =(90) \times(1+0.043)^{4} \\
& =106.5
\end{aligned}
$$

Predicted traffic volume from the year 2017 to 2022,

Traffic volume in $2022=130.2$

Predicted traffic volume during the year from 2022 to 2027:

Traffic volume in $2027=155.4$ 
Predicted traffic volume from the year 2027to the year 2035,

Traffic volume in $2035=183.4$

\subsection{Separation of the Traffic Flow}

To cause minimum disturbance to the traffic along Sri Jayewardenepura road (the main traffic flow), a flyover was proposed.

\subsection{Passenger Car Unit (PCU)Values}

In order to find out the number of lanes, it was necessary to convert the number of vehicles in to PCU. This was done using PCU equivalency factor. Each category of vehicle has a different PCU value.

\subsection{Capacity Analysis for the Flyover for a period of 20 years}

The number of lanes was found out for the flyover using the Highway Capacity Manual 1985.

$$
\begin{aligned}
& \text { Full hour volume } \quad=3955 \mathrm{vph} \\
& \text { Full hour volume } \quad=3595 \mathrm{pcu} \\
& \text { Maximum } 15 \mathrm{~min} \text { volume } \quad=1069 \mathrm{vph} \\
& \text { Peak hour factor } \quad=3955 /(4 \times 1069) \\
& =0.92 \\
& \text { Service flow rate } \quad=3595 / 0.92 \\
& \begin{array}{ll} 
& =3907 \mathrm{pcuph} \\
\text { Lane width } & =12 \mathrm{ft}
\end{array} \\
& \mathrm{f}_{\mathrm{w}} \quad=0.97 \\
& \mathrm{f}_{\mathrm{p}} \quad=1.00 \\
& \mathrm{f}_{\mathrm{E}} \quad=1.00 \\
& \mathrm{P}_{\mathrm{T}} \quad=0.063 \\
& \mathrm{P}_{\mathrm{B}} \quad=0.009 \\
& \left(\mathrm{E}_{\mathrm{T}}\right) \quad=1.7 \\
& \left(\mathrm{E}_{\mathrm{B}}\right) \quad=1.5 \\
& \mathrm{~F}_{\mathrm{HV}}=1 /\left(1+\mathrm{P}_{\mathrm{T}}\left(\mathrm{E}_{\mathrm{T}}-1\right)+\mathrm{P}_{\mathrm{B}}\left(\mathrm{E}_{\mathrm{B}}-1\right)\right) \\
& =1 /(1+0.063(1.7-1)+0.009(1.5-1)) \\
& =0.95 \\
& \mathrm{v} / \mathrm{C}=1.00 \\
& \mathrm{~N} \quad=\mathrm{SF} /\left(\mathrm{Cj} \times \mathrm{v} / \mathrm{c} \times \mathrm{F}_{\mathrm{w}} \times \mathrm{F}_{\mathrm{HV}} \times \mathrm{F}_{\mathrm{E}} \times \mathrm{F}_{\mathrm{P}}\right) \\
& =2.94=>3
\end{aligned}
$$

Therefore, three lanes in each direction would be required.

\section{Roundabout Design}

\subsection{Suitability of Roundabout Design}

The basic criteria adopted by AUSTROAD to decide on the suitability of a roundabout are indicated in Table 2.
Table2 - Suitability of roundabout

\begin{tabular}{|l|c|c|c|c|}
\hline Road & $\begin{array}{l}\text { Arterial } \\
\text { road }\end{array}$ & $\begin{array}{l}\text { Sub- } \\
\text { arterial } \\
\text { road }\end{array}$ & $\begin{array}{l}\text { Collector } \\
\text { road }\end{array}$ & $\begin{array}{l}\text { Local } \\
\text { street }\end{array}$ \\
\hline Arterial & B & B & X & X \\
Sub-arterial & - & B & B & X \\
Collector & - & - & A & B \\
Local street & - & - & - & A \\
\hline
\end{tabular}

Notation:

A - Likely to be an appropriate treatment

B - May be an appropriate treatment.

$\mathrm{X}$ - Inappropriate treatment.

\subsection{Turning Movement Data}

FromRajagiriya

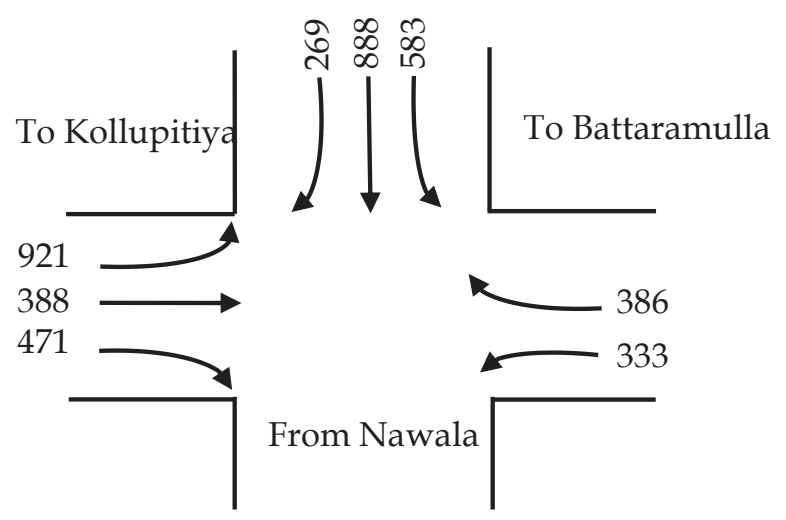

Figure 4 - Turning movement diagram (veh/h)

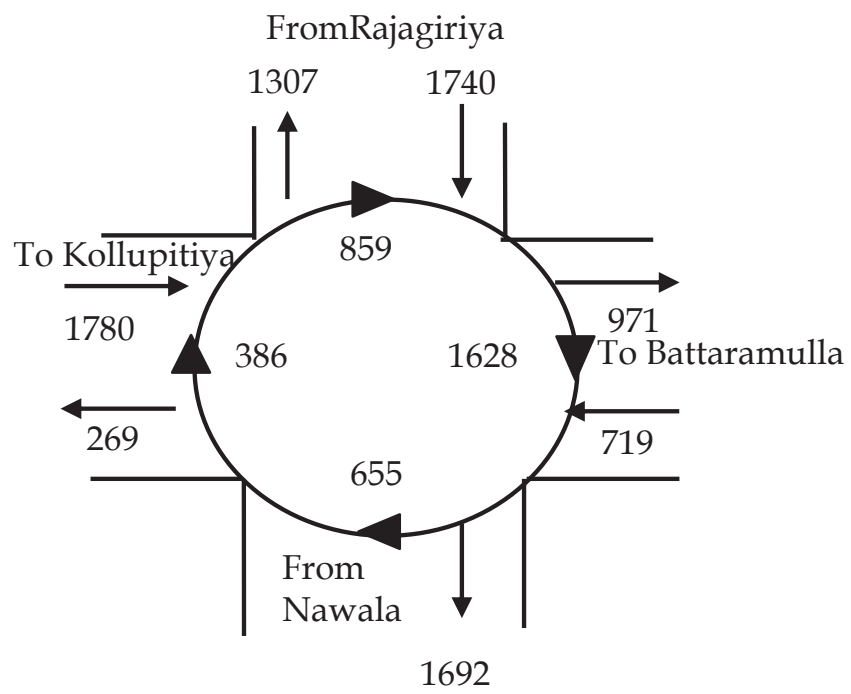

Figure 5 - Roundabout entry, exit and circulating flows (veh/h) at the Bo tree junction 
The gap acceptance parameters are affected by the geometry of the entry. At higher circulating flows, the circulating speeds would be lower.

As per AUSTROADS [2] for a multi-lane roundabout,

Critical acceptance gap $=\mathrm{T} \quad=4 \mathrm{sec}$

Follow-up headway $\quad=\mathrm{T}_{\mathrm{C}} \quad=2 \mathrm{sec}$

Minimum headway $\quad=t_{c} \quad=0 \mathrm{sec}$

\subsection{Capacity of the Entry Lanes}

Entry and circulating flows based on the turning movement data are presented in Figures 5\&6. It was necessary to find out the entry capacity of the roundabout. The traffic flow from the directions of Rajagiriya and Kollupitiya are high when compared to that which comes from the Battaramulla direction. There is no entry flow from the Nawala direction, although there is an exit flow in that direction.

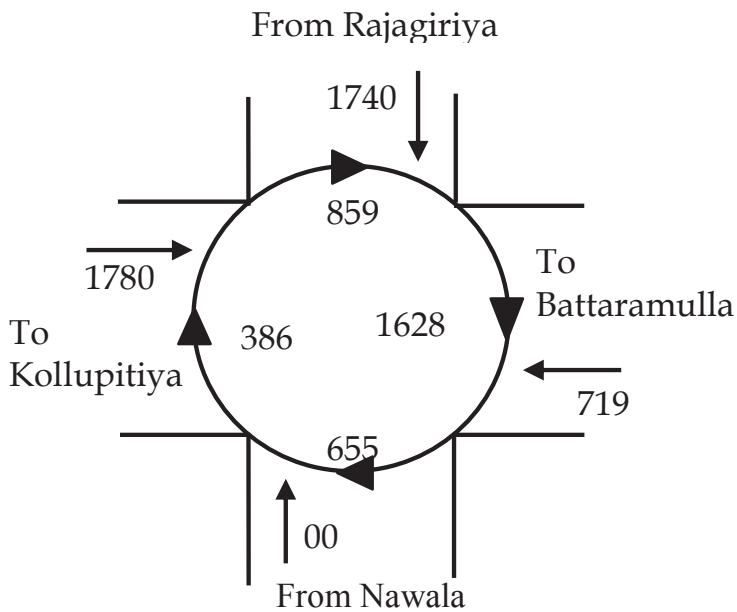

Figure 6 - Roundabout entry, exit and circulating flow $(\mathrm{pcu} / \mathrm{h})$ at the Bo tree junction

\subsection{Queuing Delay}

The average queuing delay was found using the graph obtained by plotting the average queuing delay against the circulating flow. The maximum delay is 50 seconds and none of the queuing values exceeds this maximum delay. Therefore the given queuing values would be acceptable.

\section{6 \\ Sight Triangle \& Geometric Design of the Roundabout}

For the drivers to have a clear view of the approaching traffic there has to be an area of sight unobstructed by buildings or other obstacles at the corners of an intersection.
The geometric design is very important in a roundabout design since the vehicles have to pass the roundabout easily free from accidents.

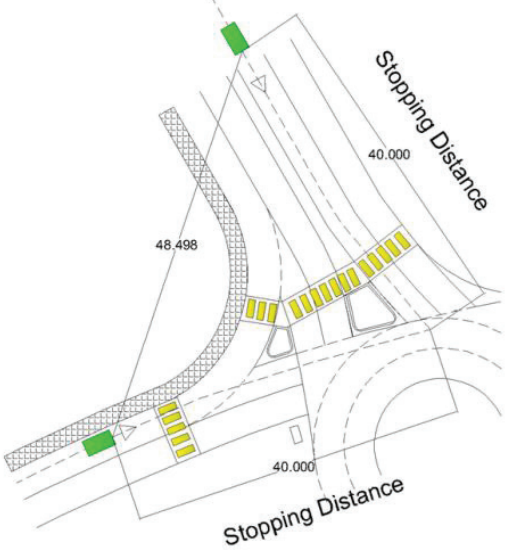

Figure 7 - Sight Triangle

\subsection{Central Island and Circulating Carriageway Width}

The design speed as the roundabout is approached is $40 \mathrm{~km} / \mathrm{h}$. The minimum central island diameter is $15 \mathrm{~m}$ and the circulating carriageway width is $11.1 \mathrm{~m}$.

\subsection{Inscribed Diameter}

The roundabout is to be located at the centerline of the intersection of roads and the inscribed diameter was found to be $37.2 \mathrm{~m}$. According to the detailed survey drawing, an inscribed diameter of 37.2 meters was found to be adequate.

Table 3 - Details of Roundabout Flows

\begin{tabular}{|c|c|c|c|c|}
\hline $\begin{array}{c}\text { Traffic flow } \\
\text { direction }\end{array}$ & $\begin{array}{c}\text { Forecast } \\
\text { traffic } \\
\text { volume } \\
\text { of entry } \\
\text { lanes } \\
\text { (vph) }\end{array}$ & $\begin{array}{c}\text { Circulating } \\
\text { flow } \\
\text { (vph) }\end{array}$ & $\begin{array}{c}\text { Maximu } \\
\text { m entry } \\
\text { capacity } \\
\text { (vph) }\end{array}$ & $\begin{array}{c}\text { Average } \\
\text { queuing } \\
\text { delay } \\
(\mathrm{sec})\end{array}$ \\
\hline $\begin{array}{c}\text { From } \\
\text { Kollupitiya }\end{array}$ & 1780 & 386 & 2592 & 7 \\
\hline $\begin{array}{c}\text { From } \\
\text { Rajagiriya }\end{array}$ & 1740 & 859 & 1960 & 41 \\
\hline $\begin{array}{c}\text { From } \\
\text { Battaramulla }\end{array}$ & 719 & 1628 & 940 & 24 \\
\hline $\begin{array}{c}\text { From } \\
\text { Nawala }\end{array}$ & 00 & 655 & 2100 & 0 \\
\hline
\end{tabular}




\section{9}

\section{Corner Radii $\left(\mathbf{R}_{3}\right)$}

Corner radii are functions of the inscribed circle radius and the approach and departure carriage way width. When two roads intersect the roads have to have equal width. For the special case where the intersecting roads are of equal width $W$, this expression simplifies to:

$$
\mathrm{R}_{3}=\mathrm{R}_{1}-2 \mathrm{~W}+\sqrt{2(R 1-W)}
$$

where,

$\mathrm{R}_{3} \quad$ - Corner radii

$\mathrm{R}_{1} \quad$-Inscribed radius $\quad=18.6 \mathrm{~m}$

W - Width between carriageway centreline and kerb on the adjacent approach and departure respectively

$$
=7.2 \mathrm{~m}
$$

$R_{3}=R_{1}-2 W+\sqrt{ } 2\left(R_{1}-W\right)$

$=9 \mathrm{~m}$

\subsection{Corner Cut-off}

The property boundaries at the corners of the intersection have to be truncated. The amount of truncation will be a function of the corner kerb radius, the footway width and the intersection angle.

The formula is $\mathrm{C}=\frac{R_{3}-W_{4}}{\tan \frac{\theta}{2}}$

where,

$$
\begin{array}{ll}
R_{3} & \text { - the kerb radius } \\
W_{4} & \text { - the footway width } \\
\theta & \text { - angle between intersecting street }
\end{array}
$$

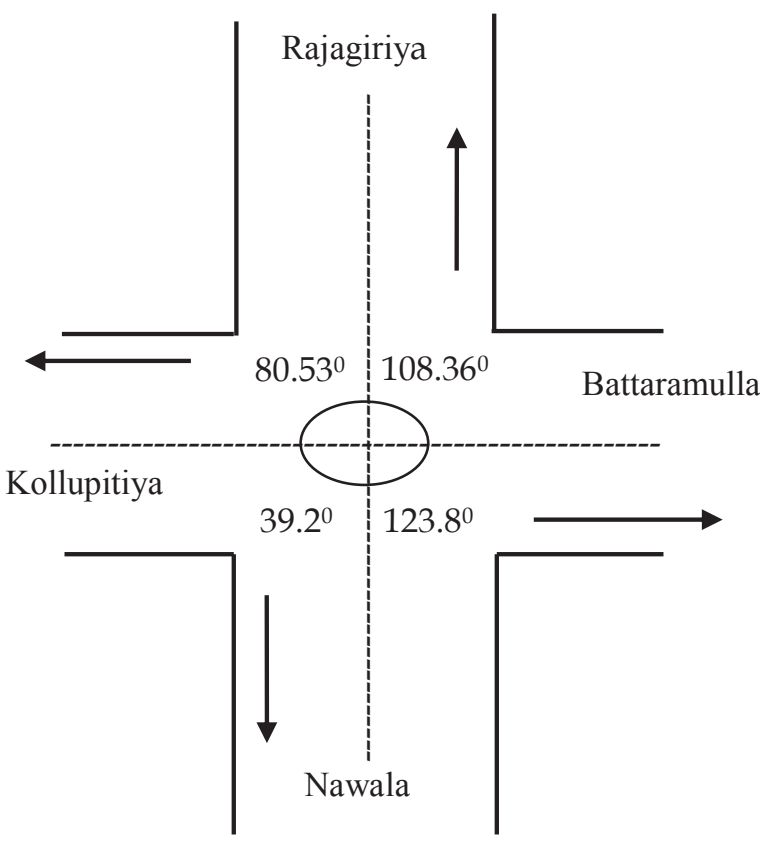

Figure 8 - Intersecting angle of street
Table 4 - Details of Corner Cut-off

\begin{tabular}{|l|c|}
\hline \multicolumn{1}{|c|}{ Direction } & $\begin{array}{c}\text { Corner Cut-off } \\
(\mathrm{C})\end{array}$ \\
\hline Nawala and Kollupitiya & $8.42 \mathrm{~m}$ \\
\hline Kollupitiya and Rajagiriya & $3.54 \mathrm{~m}$ \\
\hline Rajagiriya and Battaramulla & $2.16 \mathrm{~m}$ \\
\hline Battaramulla and Nawala & $1.60 \mathrm{~m}$ \\
\hline
\end{tabular}

\subsection{Minimum Possible Lateral Deflection into the Intersecting Street (Z)}

The deflection $\mathrm{Z}$ into the cross street is given by,

$\mathrm{Z} \quad=\mathrm{R}_{1}-\mathrm{W}_{2}+\mathrm{z}$

where,

$$
\begin{array}{lll} 
& \mathrm{W}_{2} \quad-\text { Approach width } \\
& \mathrm{Z} \quad-\text { Width of vehicle path }=2.4 \mathrm{~m} \\
\mathrm{Z} & =\mathrm{R} 1-\mathrm{W}_{2}+\mathrm{z} \\
\mathrm{Z} & =13.8 \mathrm{~m}
\end{array}
$$

\subsection{Maximum Speed of a Vehicle through the Roundabout}

The circulation of vehicle accident rate on any particular approach is largely related to the relative potential speeds of the entering and circulating vehicles. A decrease in speed will provide a number of reverse curves to the entry curve to limit the maximum decrease in speed between the horizontal geometric elements.

The maximum speed of a vehicle through a roundabout can be calculated by,

$$
\begin{aligned}
& \mathrm{V}=\sqrt{\left\{127 R_{4}(e+f)\right.} \\
& \text { where, } \\
& \mathrm{V} \quad \text { - Vehicle speed }(\mathrm{km} / \mathrm{h}) \\
& \mathrm{R}_{4} \quad \text { - Maximum path radius (m) } \\
& \text { e - Super elevation }(\mathrm{m} / \mathrm{m}) \text { [negative if } \\
& \text { the fall is from the central island] } \\
& \text { f - Allowable coefficient of friction } \\
& \text { (sideway friction between vehicle tyres } \\
& \text { and road pavement) } \\
& \text { Assuming that there is no super elevation } \\
& \text { within the roundabout } \\
& e=0, f=0.2 \\
& \mathrm{~V}=\sqrt{\left\{127 R_{4}(e+f)\right.}=39.68 \mathrm{~km} / \mathrm{h}
\end{aligned}
$$

\subsection{Splitter Island}

This is mostly used to decrease the speed at the start of the entry curve when speeds are high. Here the entry curve radius is $85 \mathrm{~m}$. The exit curve is $136 \mathrm{~m}$. The $0.3 \mathrm{~m}$ offset provides for the splitter island. The corner radius of the splitter island is $0.75 \mathrm{~m}$ and it has a $0.2 \mathrm{~m}$ thick concrete kerb. 


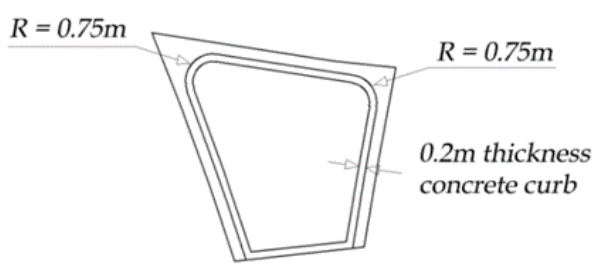

Figure 9 - Splitter island

\section{Horizontal and Vertical Alignment}

\subsection{Horizontal Alignment of the Flyover}

The horizontal alignment of the flyover is along the tangent and the curve has been designed to discourage operating speeds higher than $72 \mathrm{~km} / \mathrm{h}$. Although the existing curve 01 has been designed for $55 \mathrm{~km} / \mathrm{h}$ it is found to be not sufficient. It has to be noted that Sri Jayewardenepura road is heavily used by the Members of Parliament (MPs) as well as by Very Important Persons (VIPs).

$\mathrm{V}=17.78 \mathrm{~ms}^{-1}, \mathrm{x}=5 \mathrm{cms}^{-1}, \mathrm{C}=0.3 \mathrm{~m} / \mathrm{sec}^{2}$

" $h$ " is the amount of super elevation in centimetres.

" $x$ " is the time rate. $\left(=5 \mathrm{cms}^{-1}\right)$

"V" - Average speed of the vehicles in meters/sec

" $\mathrm{C}$ " - Rate of development of radial acceleration.

Length of transition curve (L),

$$
\begin{aligned}
\mathrm{L}_{1} & =\frac{h V}{x} \\
& =78.232 \mathrm{~m}
\end{aligned}
$$

Considering vertical acceleration

Length of transition curve (L) $=\frac{V^{3}}{R C}$

$$
\mathrm{L}_{2} \quad=92.295 \mathrm{~m}
$$

Therefore the length of transition curve

$$
=92.295 \mathrm{~m}
$$

$$
\begin{array}{ll}
\text { Shift (S) } & =\frac{L^{2}}{24 R} \\
& =\frac{92.295^{2}}{(24 \times 203)} \\
& =1.748 \mathrm{~m}
\end{array}
$$

Angle consumed by each transition $(\varphi)=\frac{L}{2 R}$

$$
\begin{aligned}
& =\frac{92.295}{(2 \times 203)} \\
& =0.227 \mathrm{rad} \quad=13^{0} 1^{\prime} 30^{\prime \prime}
\end{aligned}
$$

Total tangent length

$$
=(\mathrm{R}+\mathrm{S}) \tan (\Delta / 2)+(\mathrm{L} / 2)
$$

L - Length of transition curve

$\mathrm{R}$ - Radius of curve

\begin{tabular}{|c|c|c|}
\hline Description & Curve 01 & Curve 02 \\
\hline $\mathrm{e}$ & $6 \%$ & $6 \%$ \\
\hline $\mathrm{H}$ & $22 \mathrm{~cm}$ & $20 \mathrm{~cm}$ \\
\hline$x$ & $5 \mathrm{cms}^{-1}$ & $5 \mathrm{cms}^{-1}$ \\
\hline V & 17.78 & 17.78 \\
\hline $\mathrm{R}$ & $203 \mathrm{~m}$ & $303 \mathrm{~m}$ \\
\hline $\mathrm{L}_{1}=\frac{\boldsymbol{h} \boldsymbol{V}}{\boldsymbol{x}}$ & $78.232 \mathrm{~m}$ & 71.582 \\
\hline $\mathrm{L}_{2}=\frac{V^{3}}{R C}$ & 92.295 & 61.583 \\
\hline Shift (S) & $1.748 \mathrm{~m}$ & 0.705 \\
\hline Transition angle $(\varphi)$ & $\begin{array}{l}0.227 \mathrm{rad} \\
13^{0} 1^{\prime} 30^{\prime \prime}\end{array}$ & $\begin{array}{l}0.118 \mathrm{rad} \\
6^{0} 46^{\prime} 5^{\prime \prime}\end{array}$ \\
\hline Total Length & $161.258 \mathrm{~m}$ & $131.170 \mathrm{~m}$ \\
\hline $\begin{array}{l}\text { Angle of circular } \\
\text { curve }=\Delta-2 \varphi\end{array}$ & $32^{0} 38^{\prime} 24^{\prime \prime}$ & $21^{0} 20^{\prime} 2^{\prime \prime}$ \\
\hline $\begin{array}{l}\text { Length of circular } \\
\text { curve } \\
=[\Pi R(\Delta-2 \varphi)] / 180^{\circ}\end{array}$ & $115.644 \mathrm{~m}$ & $112.821 \mathrm{~m}$ \\
\hline Chainage A & $1268.477 \mathrm{~m}$ & $\begin{array}{c}1492.885 \\
\mathrm{~m}\end{array}$ \\
\hline $\begin{array}{l}\text { Chainage of point } \\
T_{1}^{\prime}\end{array}$ & $1107.219 \mathrm{~m}$ & $\begin{array}{c}1361.715 \\
\mathrm{~m}\end{array}$ \\
\hline Chainage of $\mathrm{T}_{2}^{\prime}$ & $1407.253 \mathrm{~m}$ & $1617.7 \mathrm{~m}$ \\
\hline
\end{tabular}

$\Delta$ - Deflection angle of the straights

Total tangent length

$=(203+1.748) \tan \left(58^{\circ} 41^{\prime} 24^{\prime \prime} / 2\right)+(92.295 / 2)$

$=161.258 \mathrm{~m}$

Angle of the circular curve $\quad=\Delta-2 \varphi$ $=32^{\circ} 38^{\prime} 24^{\prime \prime}$

Length of the circular curve $\left(\mathrm{T}_{1}{ }^{\prime \prime} \mathrm{T}_{2}{ }^{\prime \prime}\right)$

$$
\begin{aligned}
& =[\Pi R(\Delta-2 \varphi)] / 180^{\circ} \\
& =\left(\Pi \times 203 \times 32^{\circ} 38^{\prime} 24^{\prime \prime}\right) / 180^{\circ} \\
& =115.644 \mathrm{~m}
\end{aligned}
$$

$$
\begin{aligned}
& \begin{aligned}
\text { Chainage of } \mathrm{A} & =1268.477 \mathrm{~m} \\
\text { Chainage of point } \mathrm{T}_{1}{ }^{\prime} & =1268.477-161.258 \\
& =1107.219 \mathrm{~m}
\end{aligned} \\
& \begin{aligned}
\text { Chainage of } \mathrm{T}_{2}{ }^{\prime} & =\text { Chainage of } \mathrm{T}_{1}{ }^{\prime}+2 \times \\
\text { transition curve length } & + \text { Curve length } \\
= & 1107.219+115.644+2 \times 92.295 \\
= & 1407.253 \mathrm{~m}
\end{aligned}
\end{aligned}
$$

Table 5 - Horizontal Alignment

The horizontal alignment of the flyover is shown in Figure A4 of Appendix A. 


\section{2}

\section{Vertical Alignment of the Flyover}

The vertical alignment is the combination of parabolic vertical curves and the straight sections joining them. The straight sections are referred to as grades, and the values of their slope are the gradients, usually expressed as a percentage. The design speed applied to the vertical alignment should therefore match that applied to the horizontal alignment.

\subsection{Crest Curve of Vertical Alignment}

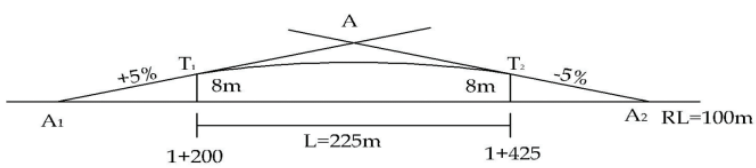

\section{Figure 10 - Crest curve}

Determination of stopping sight distance:

Design speed $=45 \mathrm{mph}(72 \mathrm{kmph})$

Grades,

$$
\begin{array}{ll}
\mathrm{g}_{1} & =+5 \% \\
\mathrm{~g}_{2} & =-5 \% \\
\mathrm{~A} & =\mathrm{g}_{1} \%-\mathrm{g}_{2} \% \\
& =5 \%-(-5 \%) \quad=10 \%
\end{array}
$$

Stopping sight distance is minimum for the vertical crest curve. The height of the eye was considered as $3.5 \mathrm{ft}(1.07 \mathrm{~m})$ on the road surface and the height of object as $2 \mathrm{ft}(0.61 \mathrm{~m})$.

\section{Chainage of $\mathrm{T}_{1}$} $=1200 \mathrm{~m}$

Reduced level of $\mathrm{T}_{1}$

$$
=108 \mathrm{~m}
$$

Equation of grade line,

$$
\begin{array}{ll}
\mathrm{Y} & =\mathrm{mx}+\mathrm{C} \\
\mathrm{Y} & =0.05 \mathrm{x}+108
\end{array}
$$

$\mathrm{L}=\mathrm{AS} 2 /\left[200(\sqrt{\mathrm{h} 1}+\sqrt{h 2})^{2}\right]$

where,

$$
\begin{aligned}
& \mathrm{h}_{1}=1.07 \mathrm{~m} \quad \mathrm{~h}_{2}=0.61 \mathrm{~m} \\
& \mathrm{~A}=10 \%
\end{aligned}
$$

Stop sight distance for $(5 \%)=393 \mathrm{ft}=120 \mathrm{~m}$

$\mathrm{L} \quad=10 \times 120^{2} /\left[200(\sqrt{1.07}+\sqrt{0.61})^{2}\right]$

$$
=218.5 \mathrm{~m}<225 \mathrm{~m}
$$

The equation of a parabolic curve is given by,

$$
\mathrm{Y}=\mathrm{ax} \mathrm{x}^{2}+\mathrm{bx}+\mathrm{c}
$$

It's gradient at a point,

$$
\frac{d y}{d x} \quad=2 \mathrm{ax}+\mathrm{b}
$$

Rate of change of gradient along the curve,

$\frac{d^{2} x}{d x^{2}} \quad=2 \mathrm{a}(\mathrm{a}$ constant $)$

$$
\begin{aligned}
\text { Mid-off set }(\mathrm{Y}) & =\mathrm{AL} / 800 \\
& =(10 \times 225) / 800=2.813 \mathrm{~m} \\
\text { Off set }(\mathrm{y}) & =\mathrm{X}^{2} \mathrm{~A} / 200 \mathrm{~A} \\
& =10 \mathrm{x}^{2} / 200 \times 225=\mathrm{x}^{2} / 4500
\end{aligned}
$$

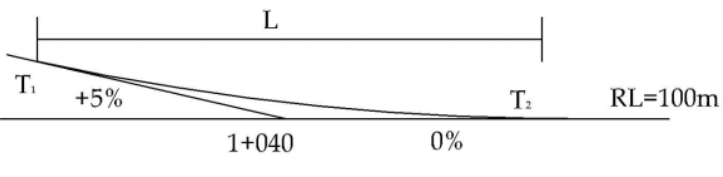

Figure 11 - Sag curve alignment

$$
\begin{aligned}
\mathrm{A} & =\mathrm{g}_{1} \%-\mathrm{g}_{2} \% \\
& =5 \%-(0 \%) \quad=5 \%
\end{aligned}
$$

Chainage of $\mathrm{A}_{2}=66.67 \mathrm{~m}$

Chainage of $\mathrm{T}_{1}=200 \mathrm{~m}$

Reduced level of $\mathrm{T}_{1} \quad=108 \mathrm{~m}$

Reduced level of $\mathrm{T}_{2} \quad=100 \mathrm{~m}$

Equation of grade line,

$$
\begin{array}{ll}
\mathrm{Y} & =\mathrm{mx}+\mathrm{c}, \\
\mathrm{Y} & =0 \mathrm{x}+100
\end{array}
$$

Consider a design speed of $45 \mathrm{mph}$ and a grade $+5 \%$ then stopping sight distance is $331.67 \mathrm{ft}(101 \mathrm{~m})$ (Design manual capacity 2003, figure 7-1A)

To find the headlamp visibility, two possible scenarios are considered.

$$
\mathrm{S} \leq \mathrm{L} \text { and } \mathrm{S} \geq \mathrm{L} \text {. }
$$

Make an angle of $+2^{0}$ with the horizontal.

Headlamp position $650 \mathrm{~mm}$ above the road surface.

For $\mathrm{S} \leq \mathrm{L}$,

$\mathrm{L} \quad=\mathrm{S}^{2} \mathrm{~A} / 200(\mathrm{~h}+\mathrm{S}$ tana $)$

where,

$\mathrm{S} \quad=101 \mathrm{~m}$

$\mathrm{H} \quad=0.65 \mathrm{~m}$

$\mathrm{A}=+2^{0}$

So,

$\mathrm{L}=\left(101^{2} \times 5\right) / 200\left(0.65+101 \times \tan 2^{\circ}\right)$

L` $\quad=61 \mathrm{~m}$

Therefore, this value is not valid.

For $S \geq \mathrm{L}$,

$\mathrm{L} \quad=2 \mathrm{~S}-200(\mathrm{~h}+\mathrm{S} \tan \mathrm{a}) / \mathrm{A}$

$\mathrm{L} \quad=2 \times 101-200\left(0.65+101 \times \tan 2^{0}\right) / 5$

$\mathrm{L} \quad=35 \mathrm{~m} \quad<101 \mathrm{~m}$

This value is valid.

Therefore sag curve length is $35 \mathrm{~m}$.

The equation of a parabolic curve is given by,

$\mathrm{Y}=\mathrm{ax}+\mathrm{bx}+\mathrm{c}$

It's gradient at a point,

$$
\frac{d y}{d x} \quad=2 \mathrm{ax}+\mathrm{b}
$$

Rate of change of gradient along the curve,

$$
\frac{d^{2} y}{d x^{2}} \quad=2 \mathrm{a} \quad \text { (a constant) }
$$

Mid off set $(Y)=A L / 800$

$$
\begin{aligned}
& =(10 \times 35) / 800 \\
& =0.438 \mathrm{~m} \\
& =X^{2} \mathrm{~A} / 200 \mathrm{~L} \\
& =5 X^{2} / 200 \times 35 \\
& =X^{2} / 1400
\end{aligned}
$$

Off set (y) 


$\begin{aligned} \text { Chainage of } \mathrm{A} & =1200-(8 / 0.05) \\ & =1040 \mathrm{~m} \\ \text { Chainage of } \mathrm{T}_{2} & =1040-(35 / 2) \\ & =1022.5 \mathrm{~m} \\ \text { Chainage of } \mathrm{T}_{1} & =1040+(35 / 2) \\ & =1057.5 \mathrm{~m}\end{aligned}$

The vertical alignment details of the flyover are shown in Figure A5 of Appendix A.

\subsection{Details of the Flyover}

Chainage at the beginning of the flyover

$$
=1022.5 \mathrm{~m}
$$

Chainage at the end of the flyover

$$
=1603.0
$$

Overall length of the flyover

$$
=1603.0-1022.5
$$$$
=580.5 \mathrm{~m}
$$

Length of the flyover $\quad=580.5 \mathrm{~m}$

Width of the flyover

$$
\begin{aligned}
& =\text { Carriageway width }+(\text { Width of } \\
& \text { clearance } \times 4)+ \text { median width } \\
& =(3.66 \times 6)+(0.3 \times 4)+0.8 \\
& =24 \mathrm{~m}
\end{aligned}
$$

\section{Structural Design of the Flyover}

\subsection{Details of the Beam Section}

Pre-stressed 'I' section beams were selected for the flyover. The maximum span was at the bay above the roundabout. The design was done according to BS 5400:1978 Part 02, BS 5400:1978 Part 04 and BS8110:1997 codes [4], [5], [6].

\subsection{Details of the Cantilever Beam}

Grade 40 concrete was used for the cantilever beam. The cantilever beam design was done according to the required dimensions. BS codes [4] \& [5] were used for the cantilever beam design.

\subsection{Details of the Piers}

Piers were designed using BS 5400 [5]. Rectangular reinforced concrete columns of grade 40 concrete were used for the piers. Cross-sections of $3 \mathrm{~m} \times 1 \mathrm{~m}$ rectangular piers were used to support the flyover deck.

\subsection{Safety on the Flyover}

The flyover has to be designed in such a way that there is the highest possible degree of safety when transporting passengers and goods by road.

At the edge of the flyover, there has to be a barrier. Barriers ensure safety of vehicles travelling below the flyover. Barriers can be made of steel, pre-stressed and in-situ concrete. For flyovers and barriers pre-stressed concrete and steel are widely used.

\subsection{Details of the Deck and the Beam of the Flyover}

Details of the deck

$\begin{array}{ll}\text { Width of a lane } & =3.66 \mathrm{~m} \\ \text { Number of lanes } & =6 \mathrm{Nos} \\ \text { Width of the carriageway } & =22 \mathrm{~m} \\ \text { Median width } & =0.8 \mathrm{~m} \\ \text { Shoulder width } & =0.3 \times 4 \\ & =1.2 \mathrm{~m} \\ \text { Therefore, } & =24 \mathrm{~m} \\ \text { Total width of flyover } & \\ \text { Details of beam } & =32 \mathrm{~m} \\ \text { Overall length of a beam } & =32-(2 \times 0.04) \\ \text { Length of a beam } & \end{array}$

\section{Conclusion}

The design of the flyover was done for the projected traffic of the year 2035 and the flyover was located in such a way so as to avoid becoming a hindrance to the three junctions. The location of the flyover was decided based on the prevailing operating conditions. Pre-stressed material was proposed for the flyover considering economic reasons with pre-stressed concrete, and in-situ concrete proposed for beams and piers respectively.

Roundabouts were found to be suitable in managing traffic flow under the flyover. The design of the roundabout was done based on Australian Standards and using turning templates. The selection and design of a roundabout, as with any intersection, requires the balancing of competing objectives. These range from transportation related factors like safety, operational performance, and accessibility for all users and other factors such as land use, aesthetics, and environment. Flexible concepts should allow room for independent designs and techniques used should cater to particular situations while ensuring performance based evaluation of those designs. Finally a suitable layout plan was introduced for the study. The design of 
the flyover will mostly dependent on land acquisition and cost.

\section{References}

[1]. Highway Capacity Manual (2000), Special Report 209, Transportation Research Board, National Research Council, Washington, D. C.

[2]. AUSTROADS (1991), Guide to Traffic Engineering practice, Part 6, 'Roundabouts', AUSTROAD Publications, NSW, Australia.

[3]. Joe Hummer, Raleigh, N. C. (2012) '2010 Highway Capacity Manual' Day 1, Unit 1,
Chapters 1-9, Virginia Transportation Training Academy

[4]. BS 5400 (1978), Part 2, Structural use of Concrete, British Standards Institution.

[5]. BS 5400 (1978), Part 4, Structural use of Concrete, British Standards Institution

[6]. BS 8110 (1997), Part 1, Structural Design with Reinforced Concrete, British Standards Institution. 
Appendix A

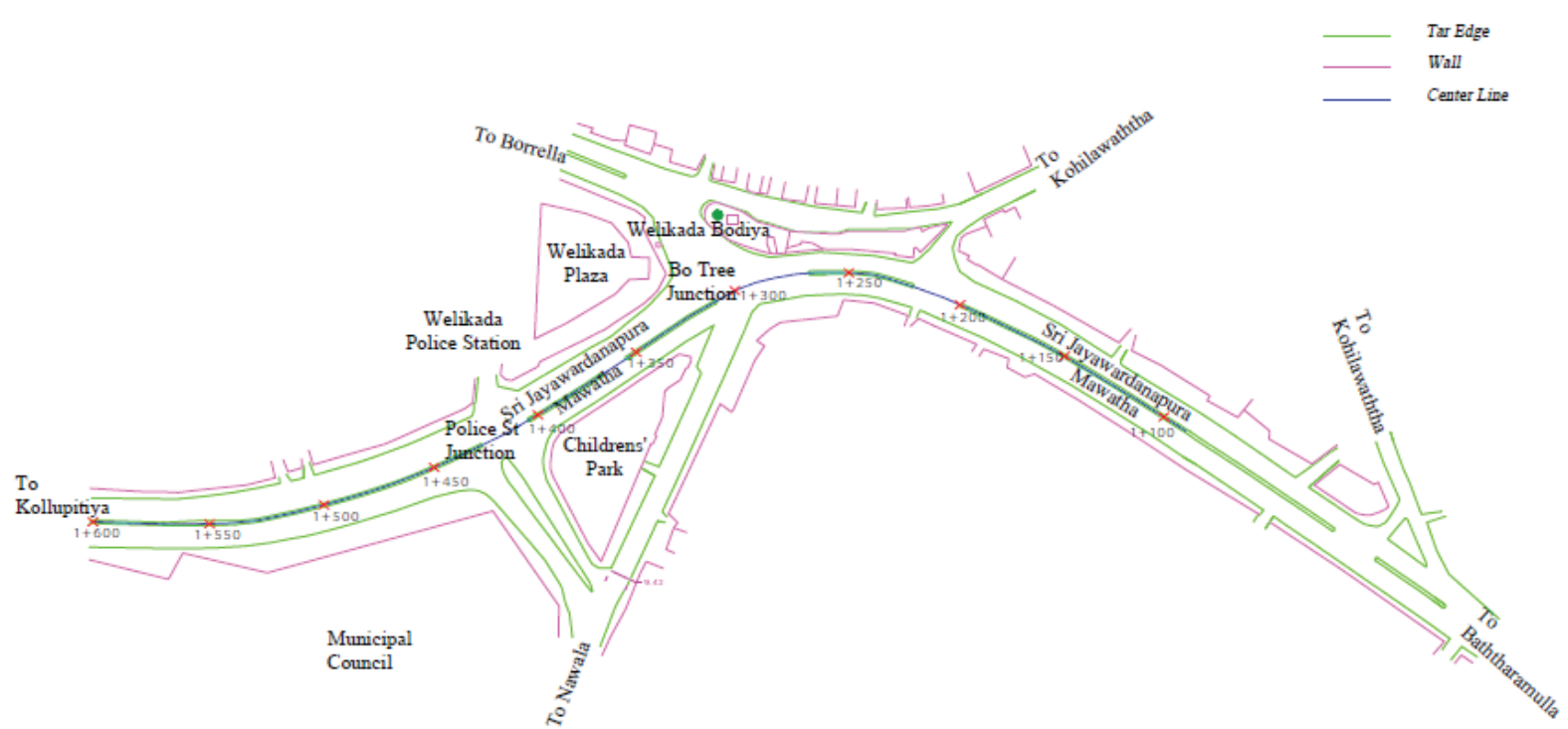

Appendix A - Figure A1 - Existing drawing at Rajagiriya junction

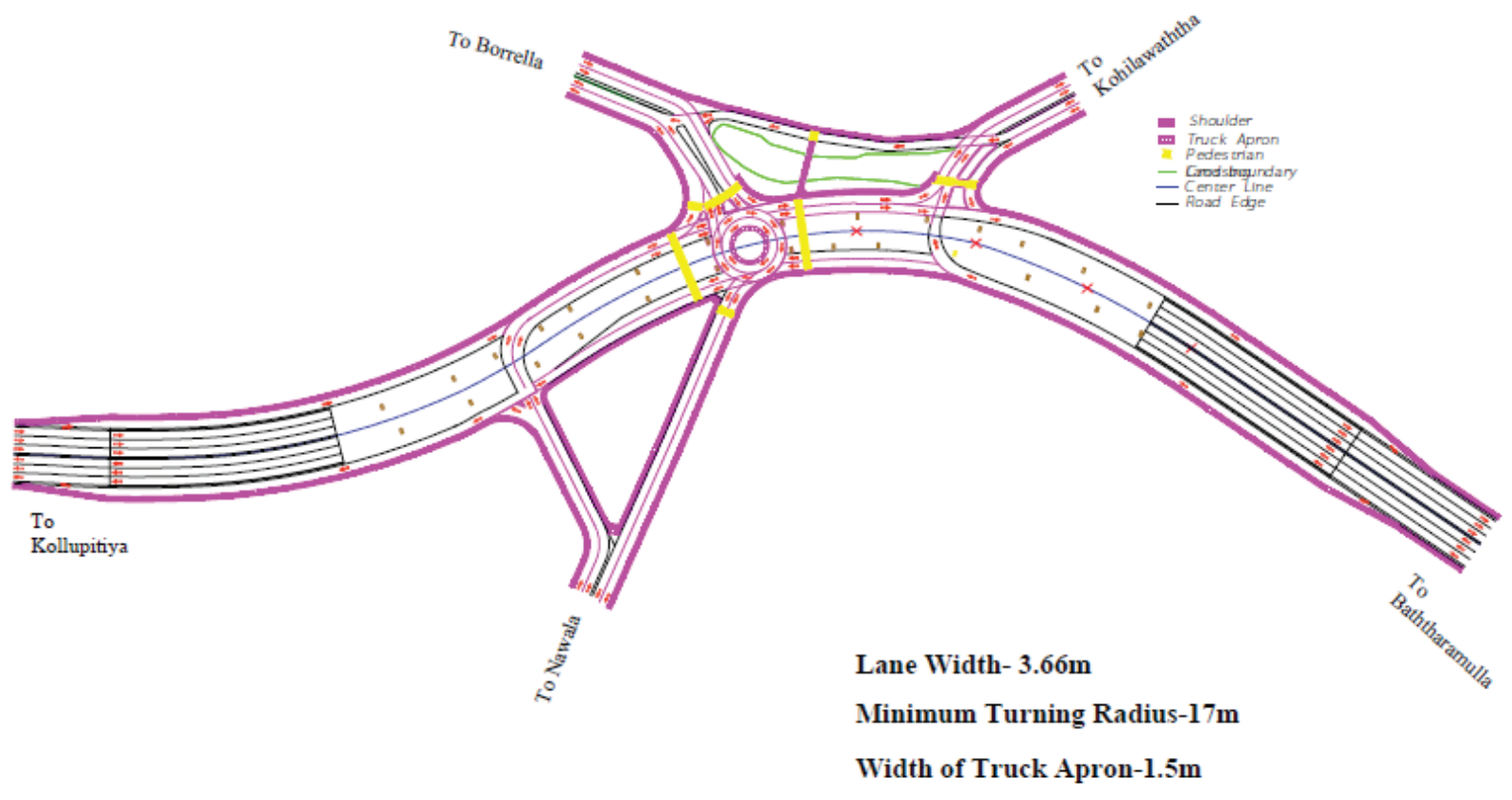

Radius of Center Island- $6.5 \mathrm{~m}$

Inscribed Diameter-30.4m

Appendix A -Figure A2 - Underneath of the Flyover 


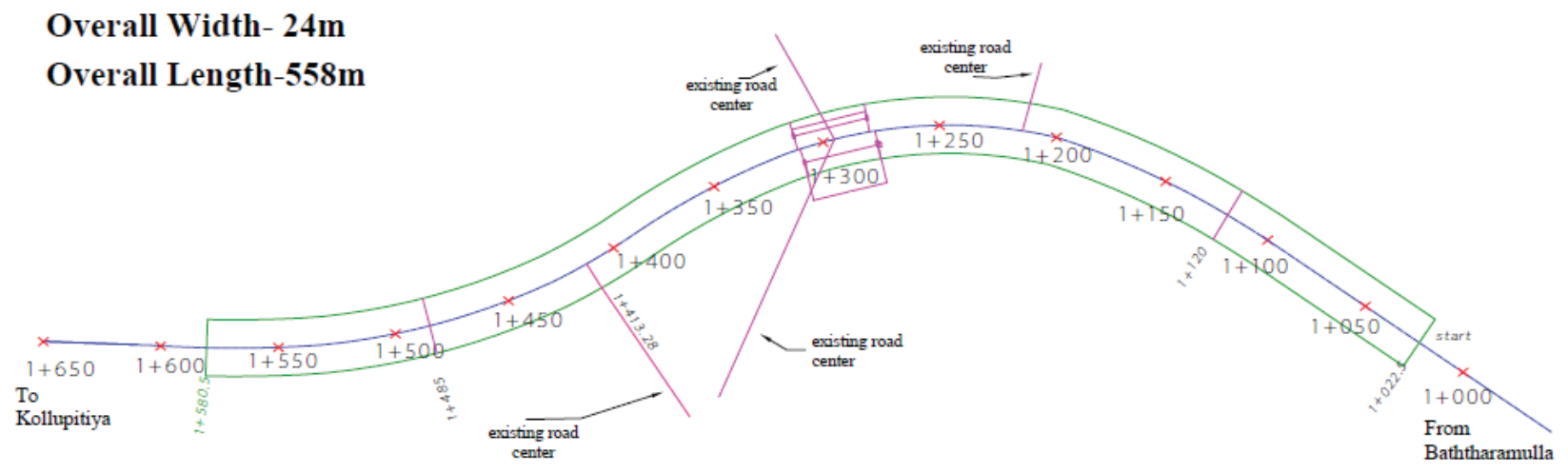

Appendix A -Figure A3 - Longitudinal Section of the Flyover

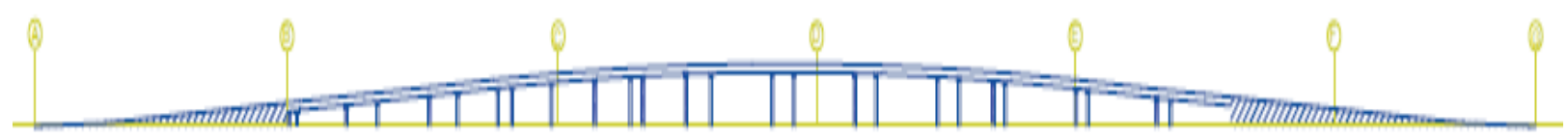

Appendix A -Figure A4 - Flyover Vertical Alignment Details

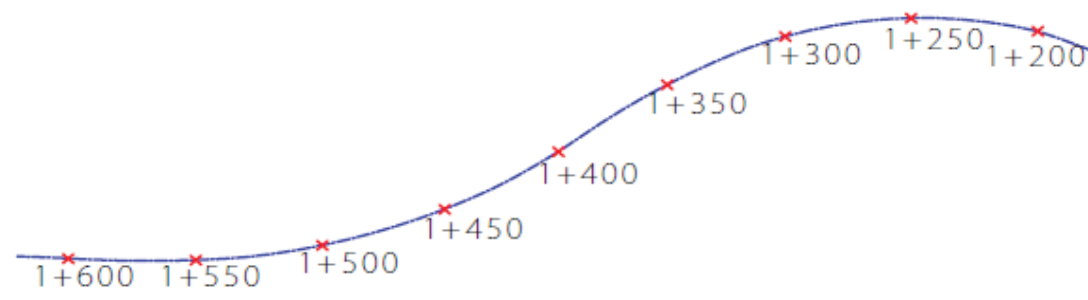

To

Kollupitiya

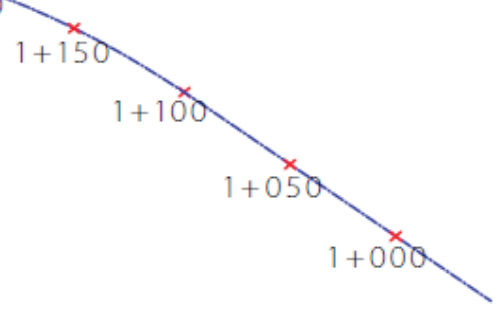

From

Baththaramulla

Appendix A -Figure A5 - Flyover Horizontal Alignment Details 


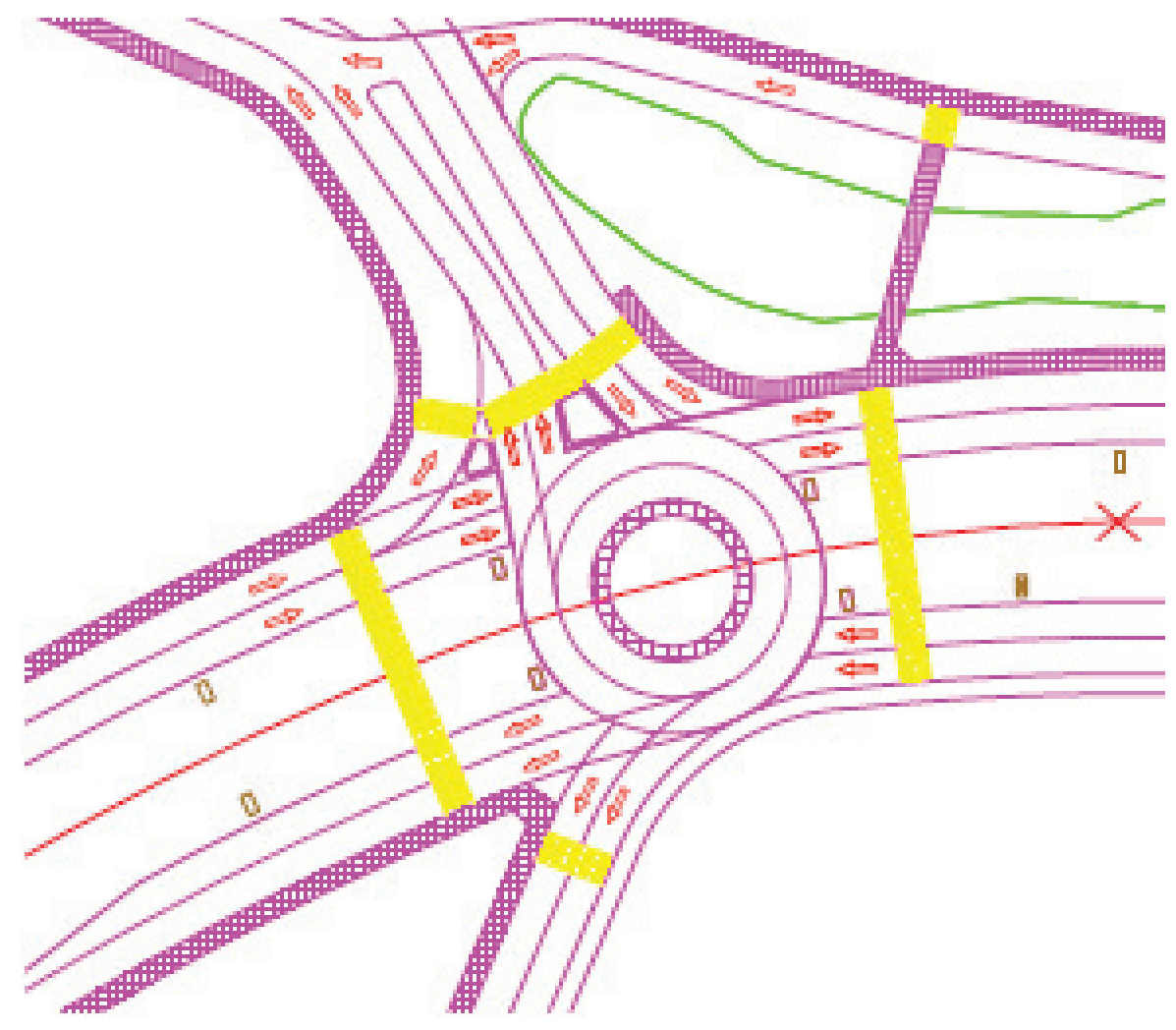

Appendix A -Figure A6 - Turning Movements Roundabout at the Bo tree junction

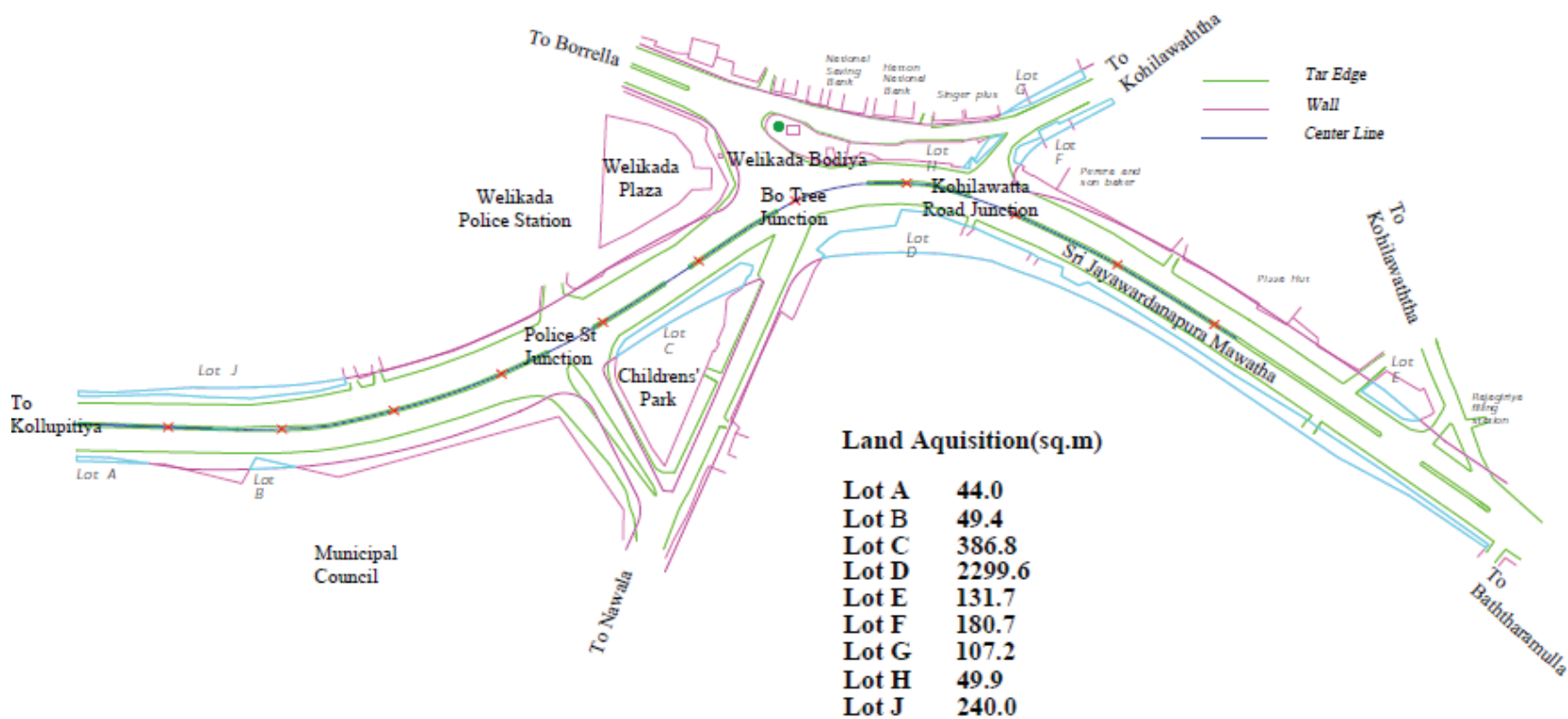

Appendix A -Figure A7 - Land Acquisition Drawing at the Rajagiriya junction 